\title{
EXPENSIVE CEREBRAL BLOOD FLOW MEASUREMENTS ALONE ARE USELESS AND MISINFORMATIVE IN COMATOSE PATIENTS
}

\section{A comprehensive alternative}

\author{
Julio Cruz'
}

\begin{abstract}
Since the first report addressing quantification of cerebral blood flow (CBF), concomitant assessment of cerebral oxygen consumption was also carried out. Over the years, however, some investigators have emphatically and mistakenly addressed cerebral ischemia in comatose patients, on the basis of CBF measurements alone. In contrast, we have repeatedly reported that ischemia in these patients must be precisely evaluated based on CBF-metabolism coupling or uncoupling, rather than CBF alone. Based on these previous findings, we therefore propose a comprehensive alternative approach, namely the evaluation of brain ischemia in comatose patients based on cerebral metabolic parameters, such as cerebral extraction of oxygen or cerebral lactate release, without expensive CBF measurements.
\end{abstract}

KEY WORDS: arteriojugular lactate difference, brain ischemia, cerebral blood flow, cerebral extraction of oxygen, coma.

\begin{abstract}
Medidas dispendiosas apenas de fluxo sanguíneo cerebral são inúteis e desinformativas em estados de coma: uma alternativa abrangente

RESUMO - Desde o primeiro artigo apresentando quantificação de fluxo sanguíneo cerebral (FSC), também se avaliou o consumo cerebral de oxigênio. Todavia, ao longo dos anos, alguns investigadores têm enfaticamente e erroneamente destacado a isquemia cerebral em pacientes comatosos, baseando-se apenas em medidas do FSC. Em contrapartida, temos repetidamente destacado que a avaliação de isquemia cerebral nestes pacientes deve ser baseada no conceito de acoplamento ou desacoplamento entre metabolismo cerebral e FSC, ao invés de alterações no FSC apenas. Baseando-se nestes achados prévios, aqui propomos uma abordagem alternativa e abrangente, a qual envolve a avaliação de isquemia cerebral em pacientes comatosos baseando-se em parâmetros metabólicos cerebrais, tais como a extração cerebral de oxigênio ou a liberação cerebral de lactato, sem medidas dispendiosas de FSC.
\end{abstract}

PALAVRAS-CHAVE: diferença artério-jugular de lactato, isquemia cerebral, fluxo sanguíneo cerebral, extração cerebral de ôxigenio, coma.

Since the pioneering work of Kety and Schmidt ${ }^{1}$, addressing quantification of cerebral blood flow (CBF), concomitant assessment of the cerebral metabolic rate of oxygen consumption $\left(\mathrm{CMRO}_{2}\right)$ was also established. CBF was precisely quantified as the integrated arteriojugular difference of nitrous oxide over approximately 10 minutes (the "height-overarea" method of quantification), whereas $\mathrm{CMRO}_{2}$ was calculated as the product of $\mathrm{CBF}$ and the arteriojugular oxygen content difference $\left(\mathrm{AVDO}_{2}\right)$. The latter parameter had already been introduced in the pertinent literature by another pioneering work of Gibbs and coworkers².
Over the years, nearly all alternative techniques proposed for CBF quantification adopted the normal CBF values reported by Kety and Schmidt for validation, even those involving modern and sophisticated positron emission tomography (PET) scanning. Therefore, arteriojugular measurements have been regarded as highly accurate by most investigators, not only for cerebral metabolic assessment but also for CBF measurements.

In recent years, however, stable xenon computerized tomography (CT) CBF measurements became available, and a number of studies have emphatically and mistakenly addressed global or regional cere-

\footnotetext{
${ }^{1}$ M.D., Ph.D., Director, The Comprehensive International Center for Neuroemergencies and Postgraduate Professor, Escola Paulista de Medicina, Federal University of São Paulo, São Paulo SP, Brazil.
}

Received 27 October 2002. Accepted 25 January 2003.

Dr. Julio Cruz - CICNEM - Caixa Postal 57011 - 04093-970 São Paulo SP - Brasil. 
bral ischemic changes in comatose patients ${ }^{3-5}$. The most elementary mistake in all these papers is that ischemia was defined as CBF levels of $18 \mathrm{ml} / 100 \mathrm{~g} /$ min or less, based on previously reported work addressing ischemic changes at such CBF levels, but in the awake monkey brain ${ }^{6}$.

Because the awake brain presents with normal oxygen consumption, it is expected that a reduction in CBF from normal $50 \mathrm{ml} / 100 \mathrm{~g} / \mathrm{min}$ to $18 \mathrm{ml} / 100$ $\mathrm{g} / \mathrm{min}$ may, in fact, lead to cerebral ischemic changes. Unlike the awake monkey brain, however, CBF reductions to approximately $20 \mathrm{ml} / 100 \mathrm{~g} / \mathrm{min}$ in awake human brain have not resulted in any neurological deficit $^{7}$. In this latter study by Finnerty and coworkers, cerebral oxygen extraction increased to compensate for the CBF reduction, but no evidence of cerebral ischemia was found on clinical grounds.

Because cerebral oxygen consumption has been invariably reported as largely decreased in comatose patients ${ }^{8-15}$, and by simply applying to cerebral physiology the basic notion of proportionality, it therefore became clear to us that ischemic CBF thresholds in the comatose brain must be lower than $20-18 \mathrm{ml} /$ $100 \mathrm{~g} / \mathrm{min}$. In this respect, we first reported a well documented case where CBF spontaneously dropped to as low as $10 \mathrm{ml} / 100 \mathrm{~g} / \mathrm{min}$ in a comatose patient, and excellent neurological recovery could still be observed after 45 days only 9 . Most recently, Diringer and coworkers ${ }^{16}$ have intentionally dropped regional CBF levels to as low as $8 \mathrm{ml} / 100 \mathrm{~g} / \mathrm{min}$, also in comatose patients, and found no metabolic evidence of ischemia based on sophisticated PET scanning.

From the above discussion, it becomes clear that all studies addressing CBF measurements alone (without concomitant metabolic data) have invariably introduced mistaken, perhaps intentional misinformation in the field of cerebral hemodynamics applied to comatose patients. This is particularly true for studies involving stable xenon CT-CBF measurements $s^{3-5}$, besides less frequently used single photon emission computerized tomography (SPECT) CBF studies, which simply do not provide any metabolic information.

\section{CBF-metabolism coupling}

As described earlier, $\mathrm{AVDO}_{2}$ is the ratio of $\mathrm{CMRO}_{2}$ to CBF. However, we have found that $\mathrm{AVDO}_{2}$ frequently underestimates cerebral oxygen extraction in mild or profound acute anemia, a frequent finding during intensive care ${ }^{10,17}$. We have therefore introduced in the pertinent literature two novel parameters, which were termed cerebral extraction of oxygen $\left(\mathrm{CEO}_{2}\right)$ and cerebral consumption of oxygen $\left(\mathrm{CCO}_{2}\right)^{10}$. $\mathrm{CEO}_{2}$ (the arteriojugular oxyhemoglobin saturation difference) and $\mathrm{CCO}_{2}$ (the product of $\mathrm{CBF}$ and $\mathrm{CEO}_{2}$ ) are accurate variables in either anemic or non anemic conditions, and therefore became better alternative measurements than the conventional $\mathrm{AVDO}_{2}$ and $\mathrm{CMRO}_{2}$. These interrelationships are expressed by the following equation:

$$
\mathrm{CEO}_{2}=\mathrm{CCO}_{2} / \mathrm{CBF} * 100
$$

The simple inspection of this equation reveals that, without the need to measure $\mathrm{CBF}$ and $\mathrm{CCO}_{2}$, a normal (or therapeutically normalized) $\mathrm{CEO}_{2}$ value will accurately indicate adequate global CBFmetabolism coupling. Accordingly, an increased (widened) $\mathrm{CEO}_{2}$ will indicate a condition of relative cerebral hypoperfusion, where CBF is reduced in relation to the oxygen demand, consistent with a preischemic or truly ischemic finding, depending on the magnitude of the $\mathrm{CEO}_{2}$ increase. In our experience, the normal $\mathrm{CEO}_{2}$ ranges are $24-42 \%$ in adults ${ }^{10,18-21}$ and $17-35 \%$ in children ${ }^{19,22}$, so that values above the upper normal limits would require therapies to increase CBF (again, without the need for CBF measurements).

Conversely, a decreased (narrowed) $\mathrm{CEO}_{2}$ will indicate a condition of relative cerebral hyperperfusion, where CBF is increased relative to oxygen demand. Under these circumstances, cerebral vasoconstrictive therapies may be indicated, especially in the presence of elevated intracranial pressure (ICP).

\section{Phasic physiological changes}

Lassen $^{23}$ first reported abnormally increased CBF following clinically suspected cerebral hypoxic or ischemic events, a surprising condition defined as "luxury perfusion syndrome". Indeed, based on Lassen's experience, this secondary hyperperfusional state may be expected in patients with acute ischemic stroke, following an initial CBF reduction. The exact underlying mechanism responsible for such phasic changes remains unknown, however.

In comatose patients with severe acute brain trauma, we first reported in recent studies that phasic $\mathrm{CEO}_{2}$ changes are also frequent, both in adults 20,21 and children ${ }^{22}$. Unlike Lassen's experience with CBF measurements, we did not have clear clinical evidence of an initial hypoxic or ischemic insult, but normal or mildly increased $\mathrm{CEO}_{2}$ values on the first postinjury day were frequently replaced by decreased $\mathrm{CEO}_{2}$ during most of the acute phase of illness ${ }^{20-22}$. These important phasic changes, however, have not even been addressed by those who have only focused on reduced CBF alone (without mandatory metabolic data), and have invariably and mistakenly addressed ischemia in a grossly biased fashion ${ }^{3-5}$.

\section{Consciousness versus coma}

The aforementioned controversial findings must 
be interpreted on the basis of the patient's level of consciousness, as well as the disease process. Indeed, if a patient becomes unconscious immediately after the brain insult (such as severe trauma), a global decrease in $\mathrm{CCO}_{2}$ is expected, until the patient recovers consciousness and $\mathrm{CCO}_{2}$ physiologically increases. Under these circumstances, it is just expected that truly ischemic CBF thresholds will not be found, at least during intensive care. Indeed, the metabolic parameters involving arteriojugular oxygen $\left(\mathrm{CEO}_{2}\right)$ and lactate differences have recently essentially ruled out cerebral ischemia in two large series of patients reported by our team ${ }^{20,21}$.

In the initially conscious patient (such as in ischemic stroke or cerebral vasospasm in aneurysmal subarachnoid hemorrhage), however, ischemic CBF thresholds are expectedly higher than in the initially comatose patient, because $\mathrm{CCO}_{2}$ is initially normal. Accordingly, therapies to increase CBF are logical in most of these conscious patients. In addition, if there is a clear cause-and-effect relationship between acutely reduced CBF and the state of coma or even just focal neurological deficits, manipulating CBF upward would always seem advisable. Once the state of coma is diagnosed without clear evidence that reduced CBF was the triggering event, however, therapies aiming at upward CBF changes would seem to be ilogical, because CBF would just exceed the globally reduced $\mathrm{CCO}_{2}$ and, in patients with acutely decreased cerebrospinal fluid spaces, increasing CBF therapeutically may induce dangerous ICP increases.

Therefore, on practical grounds, it is extremely difficult to make decisions regarding therapeutic upward CBF manipulations in a comatose patient, whereas such decision-making process is easy in the conscious patient, especially in the presence of localizing neurological signs and a well established diagnosis showing that reduced CBF was the primary adverse event. While this condition is clear in acute ischemic stroke and vasospasm following aneurysmal subarachnoid hemorrhage, the same is not true in many comatose patients who present at the hospital with other disease processes.

\section{Diagnosing brain ischemia}

Based on our extensive previously published experience ${ }^{9-11,18-22}$, we hereby propose that CBF measurements be definitively abandoned, and replaced by cerebral metabolic parameters. For global assessment, $\mathrm{CEO}_{2}$ has been the most practical and inexpensive option, for both adults ${ }^{10,18,20,21}$ and children ${ }^{22}$. The arteriojugular lactate difference (AVDL) may also be used ${ }^{20,21}$, but it is more expensive and technically more cumbersome. The combination of $\mathrm{CEO}_{2}$ and AVDL measurements certainly and accurately will inform about global brain ischemia or its reciprocal (relative hyperperfusion), as we have recently reported for the first time in adults ${ }^{20,21}$. AVDL measurements are not yet used for children, because of the lack of normal data in the pertinent literature.

For regional information, PET scanning is the best technique, but it is expensive, involves lenghty procedures, and is formally contraindicated for patients with suspected or confirmed intracranial hypertension, because the patient's head is placed flat for prolonged periods. The same applies to functional magnetic resonance imaging, which also provides regional cerebral metabolic information, but cannot be used for these unstable patients, because dangerous ICP increases may occur due to lowering the head as well.

Finally, regional information addressing CBF alone, as described earlier, should be definitively abandoned, not only because it provides absolutely no information with respect to CBF-metabolism coupling, but also because unstable patients with intracranial hypertension will be at increased risk of developing lethal tentorial herniation, for having the head positioned flat during the CT-CBF studies (as also happens with PET and functional magnetic resonance imaging). Therefore, on practical grounds, regional information regarding brain ischemia is still an "impossible dream" and, besides clinical information and cerebral angiography, true metabolic confirmation of regional cerebral ischemia would appear to be unfeasible under most circumstances, at least for acutely unstable patients.

\section{Transcranial doppler is not an alternative}

Unlike suggested by some investigators, transcranial doppler (TCD) assessment is not regional, but segmentary, involving only large intracranial vessels. Because cerebrovascular resistance may change at the microcirculatory level, in response to macrocirculatory abnormalities detected by TCD, true tissue ischemia cannot be confirmed by TCD measurements, in any disease process. This is particularly true in comatose patients, because global cerebral metabolic supression represents a general rule and, therefore, even gross TCD abnormalities may be clinically irrelevant in comatose patients. In conscious or semicomatose patients, however, serial (not single) TCD assessment may allow for better selection of candidates to undergo cerebral angiography and, eventually, angioplasty in cerebral vasospasm associated with aneurysmal subarachnoid hemorrhage. In contrast, TCD diagnosis does not apply to brain trauma or even acute ischemic stroke, where TCD has not been demonstrated as capable of changing therapeutic decisions. 
An additional limitation of TCD in comatose patients is that changes in flow velocity, sometimes speculated as indicative of vasospasm, may just represent reduced $\mathrm{CBF}$ which, at the microcirculatory level (not assessable by TCD measurements), represents nothing but normal coupling between low blood flow and reduced $\mathrm{CCO}_{2}$.

\section{Dangerous brain tissue probes}

In recent years, acute placement of brain tissue probes has been proposed, focusing on microdialysis (for measurements of brain tissue lactate, glucose, etc), focal oxygen tension monitoring, or even focal brain temperature assessment. Even though these expensive monitoring devices have been approved for clinical use, such approval should never have occurred, because normal values are not even known for any type of brain tissue probe measurement. Indeed, healthy human beings will never volunteer to have their heads open for any type of brain tissue probe to be placed in their brains.

Despite the total lack of knowledge regarding normal physiological values by these probes, focal "brain ischemia" has been reported in terms of "low oxygen" and "high lactate" 24 . In this respect, it is obvious that any brain tissue probe causes focal microvascular compression and distortion, which may well explain focal microcirculatory compressive hypoxia, with resulting increase in lactate concentration, findings that would be just artifactual, however. Another highly biased report addressed focal "brain ischemia" associated with hyperventilation, even when jugular oxygen values were normal or high, but the brain tissue oxygen probe showed socalled "critically low" levels ${ }^{25}$. Because this kind of intentional misinformation may have serious implications with respect to patient care, a thorough discussion regarding the total lack of validation of any type of brain tissue probe has recently been published by our team ${ }^{26}$. It is therefore hoped that all these brain tissue probes will be definitively abandoned, because they are highly invasive and normal values are not even known, and their use has obviously been recently defined as animal experimentation in humans ${ }^{26}$.

\section{Future prospects}

In light of the aforementioned clinically relevant limitations in assessing regional cerebral metabolic patterns associated with ischemia, it remains for global arteriojugular measurements to be further explored as clinically reliable guides for a variety of therapeutic approaches, which may be adopted in a broad spectrum of acute disease processes, whereas truly reliable regional information will still require future alternative methodologies and techniques, es- pecially for acutely unstable patients with suspected or confirmed intracranial hypertension. For more stable patients, however, currently available techniques (such as PET or functional magnetic resonance imaging) are helpful but expensive, so that they have not yet become routine procedures in most hospitals worldwide.

\section{REFERENCES}

1. Kety SS, Schmidt CF. The nitrous oxide method for the quantitative determination of cerebral blood flow in man: theory, procedure, and normal values. J Clin Invest 1948;27:476-483.

2. Gibbs EL, Lennox WG, Nims LF, Gibbs FA. Arterial and cerebral venous blood. Arterial-venous differences in man. J Biol Chem 1942;144:325-332.

3. Bouma GI, Muizelaar JP, Stringer WA, Choi SC, Fatouros P, Young HF. Ultra-early evaluation of regional cerebral blood flow in severely headinjured patients using xenon-enhanced computerized tomography. J Neurosurg 1992;77:360-368

4. Oettingen GV, Bergholt B, Gyldensted C, Astrup J. Blood flow and ischemia within traumatic cerebral contusions. Neurosurgery 2002;50:781-790.

5. Schroder ML, Muizelaar JP, Kuta AJ. Documented reversal of global ischemia after removal of an acute subdural hematoma: report of two cases. J Neurosurg 1994;80:324-327.

6. Jones TH, Morawetz RB, Crowell RM, et al. Thresholds of focal cere bral ischemia in awake monkeys. J Neurosurg 1981;54:773-782

7. Finnerty AF Jr, Witkin L, Fazekas JF. Cerebral hemodynamics during cerebral ischemia induced by acute hypotension. J Clin Invest 1954;33:1227-1232.

8. Bruce DA, Langfitt TW, Miller JD, et al. Regional cerebral blood flow, intracranial pressure, and brain metabolism in comatose patients. J Neurosurg 1973;38:131-144.

9. Cruz J. Low clinical ischemic threshold for cerebral blood flow in severe acute brain trauma. Case report. J Neurosurg 1994;80:143-147.

10. Cruz J, Jaggi JL, Hoffstad OJ. Cerebral blood flow and oxygen consumption in acute brain injury with acute anemia: an alternative for the cerebral metabolic rate of oxygen consumption? Crit Care Med 1993;21:1218-1224.

11. Cruz J, Jaggi JL, Hoffstad OJ. Cerebral blood flow, vascular resistance, and oxygen metabolism in acute brain trauma: redefining the role of cerebral perfusion pressure? Crit Care Med 1995;23:1412-1417.

12. Jaggi JL, Obrist WD, Gennarelli TA, Langfitt TW. Relationship of early cerebral blood flow and metabolism to outcome in acute head injury.J Neurosurg 1990;72:176-182.

13. Obrist WD, Langfitt TW, Jaggi JL, Cruz J, Gennarelli TA. Cerebral blood flow and metabolism in comatose patients with acute head injury. Relationship to intracranial hypertension. J Neurosurg 1984;61:241-253.

14. Shalit MN, Beller AJ, Feinsod M. Clinical equivalents of cerebral oxygen consumption in coma. Neurology 1972;22:155-160.

15. Tabaddor K, Bhushan C, Pevsner PH, Walker AE. Prognostic value of cerebral blood flow (CBF) and cerebral metabolic rate of oxygen $\left(\mathrm{CMRO}_{2}\right)$ in acute head trauma. J Trauma 1972;12:1053-1055.

16. Diringer MN, Videen TO, Yundt K, et al. Regional cerebrovascular and metabolic effects of hyperventilation after severe traumatic brain injury. J Neurosurg 2002;96:103-108.

17. Cruz J, Hoffstad OJ, Jaggi JL. Cerebral lactate-oxygen index in acute brain injury with acute anemia: assessment of false versus true ischemia. Crit Care Med 1994;22:1465-1470.

18. Cruz J. The first decade of continuous monitoring of jugular bulb oxyhemoglobin saturation: management strategies and clinical outcome. Crit Care Med 1998;26:344-351.

19. Cruz J, Minoja G, Mattioli C, et al. Severe acute brain trauma. In Cruz J (ed). Neurologic and Neurosurgical Emergencies. Philadelphia: W.B. Saunders Co., 1998:405-436.

20. CruzJ,Minoja G, Okuchi K. Improving clinical outcomes from acute subdural hematomas with the emergency preoperative administration of high doses of mannitol: a randomized trial. Neurosurgery 2001;49:864-871.

21. Cruz J, Minoja G, Okuchi K. Major clinical and physiological benefits of early high doses of mannitol for intraparenchymal temporal lobe hemorrhages with abnormal pupillary widening: a randomized trial. Neurosurgery 2002;51:628-638.

22. Cruz J, Nakayama P, Imamura JH, Rosenfeld KGW, de Souza HS, Giorgetti GVF. Cerebral extraction of oxygen and intracranial hypertension in severe, acute, pediatric brain trauma: preliminary novel management strategies. Neurosurgery 2002;50:774-780.

23. Lassen NA. The luxury-perfusion syndrome and its possible relation to acute metabolic acidosis localized within the brain. Lancet 1966;ii:1113-1115.

24. Menzel M, Doppenberg EMR, Zauner A, Soukup J, Reinert MM, Bullock $\mathrm{R}$. Increased inspired oxygen concentration as a factor in improved brain tissue oxygenation and tissue lactate levels after severe human head injury. J Neurosurg 1999;91:1-10.

25. Imberti R, Bellinzona $G$, Langer $M$. Cerebral tissue $\mathrm{PO}_{2}$ and $\mathrm{SjvO}_{2}$ changes during moderate hyperventilation in patients with severe traumatic brain injury. J Neurosurg 2002;96:97-102.

26. Cruz J. Hyperventilation (Letter). J Neurosurg 2002;97:1001-1002. 